\section{The institutionalization of cooperation: An institutional work analysis in a vulnerable community of the Amazon region}

\author{
Ana Maria de Lima ${ }^{1}$ \\ ${ }^{1}$ Universidade do Estado de Mato Grosso, Campus de Juara, Juara - Brazil \\ Alsones Balestrin ${ }^{2}$ \\ Kadigia Faccin ${ }^{2}$ \\ Diego Marconatto ${ }^{2}$ \\ ${ }^{2}$ Unisinos, Escola de Gestão e Negócios, Porto Alegre - Brazil
}

Received on $12 / 29 / 2017$

Approved on

$01 / 16 / 2019$

Responsible editor:

Prof. Dr. João Maurício

Boaventura

\section{Evaluation process:}

Double Blind Review

\begin{abstract}
Purpose - To provide a broader perspective on how the institutionalization of cooperation (in a network) through the work practices of local actors can generate a positive social impact and reduce social vulnerability

Design/methodology/approach - We analyzed the experience of many local actors in the Brazilian Amazon region, who cooperate in the extraction and processing of Brazil nuts, up to the formation of a collaborative network. Interviews were conducted and we became immersed in the field. In addition, we used secondary documents

Findings - The network cooperation around the extraction and processing of Brazil nuts unfolds over sequential phases throughout collaborative projects that help to reduce social vulnerability.

Originality/value - We discovered a hierarchical relationship between the types of institutional work carried out to institutionalize cooperation and we highlighted that some types of institutional work can develop different conditions for the establishment of business networks.
\end{abstract}

Keywords - cooperation, institutional work, work practices.

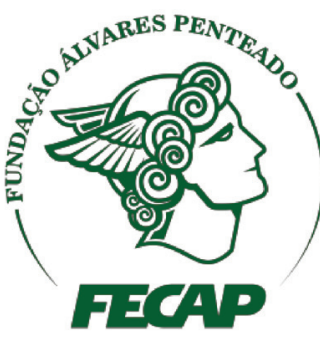

Review of Business Management 


\section{Introduction}

Social vulnerability refers to the condition of groups of individuals who are socially excluded, mainly due to socioeconomic factors. According to the United Nations Development Programme (UNDP), persistent vulnerability threatens human development. The report entitled Towards human resilience: sustaining Millennium Development Goals progress in an age of economic uncertainty points to the fact that, although the number of people who live under social vulnerability conditions has been reduced worldwide in recent years, almost 1.5 billion people in 91 developing countries still live in poverty and are deprived of access to basic health programs, education, and adequate living standards (United Nations, 2006).

Regarding the vulnerability issue, the UNDP highlights the need for policies and social norms so that progress can be equitable and sustainable. Thus, it is important to understand what types of policies, norms, behaviors, and social practices have been successful in the fight against social vulnerability. Some important initiatives have demonstrated that cooperation among local actors may develop practices that promote changes in their socioeconomic context. Thus, understanding interorganizational relationship dynamics may be a way for communities living in adverse conditions to achieve important results in terms of local development (Geddes, 2014).

The institutional work theory has been useful for understanding how cooperation networks have been created to promote changes in the institutional environment. It has focused on understanding actors' roles in relation to institutions and their mutual influences (Lawrence, Suddaby, \& Leca, 2011). In hostile environments whose individual actors have a limited ability to influence and change their social and economic conditions, cooperation becomes a relevant mechanism, particularly regarding access to and complementarity of scarce resources. Therefore, this study aims to answer the following question: how does the institutionalization of cooperation occur based on work practices among local actors in a vulnerable community? To answer this question, we sought to understand the practices of local actors that have consolidated cooperation for the development of a vulnerable community in the Amazon, known in the region as the Vale do Amanhecer Settlement (AVA).

\section{Institutional Work Theory}

The institutional work theory seeks to comprehend the relationship between actors and institutions and to understand the role of the individual in relation to institutions and the mutual influence between the individual and institutions (Lawrence et al., 2011). For Lawrence et al. (2011), institutions are elements of social life that affect actors' behavior and beliefs. Social actions for institutional maintenance must support, repair, or create social mechanisms that ensure compliance with established standards. Institutions are maintained because of their submission to norms, rules, and beliefs (Lawrence \& Suddaby, 2006). "Work" may be considered as any physical or mental effort performed with a determined goal and may create, maintain, or interrupt an institution (Lawrence et al., 2011). Institutions do not control human conduct, but it is institutional work that establishes and maintains daily routines, according to the objectives of the actors (Willmott, 2011).

As institutional work suggests the shift from a macro to a micro perspective in institutional analysis theory, another theoretical perspective has emerged highlighting the role of individuals in institutional dynamics. This perspective, known as institutional entrepreneurship, also sees the individual as the main actor in ruptures in institutions (DiMaggio, 1988), but it deals with a voluntarist view (Willmott, 2011). The distinction between the two perspectives is rather tenuous, but some characteristics are important for differentiation. Institutional work focuses on the everyday practices and strategies by which individuals and groups of individuals intentionally shape the institutional patterns in which they 
operate (Dover \& Lawrence, 2010), an ongoing process that evolves and adjusts over time (Styhre, 2014). This vision goes beyond the simple heroic act raised by the institutional entrepreneurship perspective (Willmott, 2011). While institutional work focusses on practices that lead to institutional dynamics, institutional entrepreneurship focusses on individuals themselves and their intentional efforts to question institutional standards (Styhre, 2014).

Institutional work has as its central axis the focus on the daily practices and strategies adopted by individuals or a group of individuals to build the institutional behaviors that they use to operate (Dover \& Lawrence, 2010). Practices are performed by individual and collective actors, leading to the creation, maintenance, or disruption of institutions (Lawrence \& Suddaby, 2006, p. 215). Collective actors may be state organizations (Dobbin, 2001), large corporations (Garud, Jain, \& Kumaraswamy, 2002), or professional associations (Greenwood, Oliver, Sahlin, \& Suddaby, 2008).

Institutional work suggests that institutionalization occurs in a continuous, permanent, and processual manner. In the field of institutional work, studies are designed and oriented towards the development of integrative dynamics, which allows researchers to appreciate the variety of works whose aim is to create, maintain, and interrupt institutions in the same context (Zietsma \& Lawrence, 2010). The literature offers different typifications of institutional work practices depending on objectives and characteristics. Lawrence and Sudabby (2006) proposed the main framework for types of institutional work. Regarding the creation of new institutions, several examples of institutional work practices depict three distinct groups: political, technical, and cultural work (Lawrence \& Sudabby, 2006). Political work aims to influence the development of rules, property rights, and limits and refers mainly to the regulatory pillar of institutions. It also includes activities that defend practices of other actors through direct social persuasion, defining limits between those inside and those outside the social system. Technical work provides an institution with a degree of rigor and ensures that the work can be more easily transported from one environment to another. Technical work is less effective in bringing and connecting actors to the institution. Meanwhile, cultural work involves the presentation of an institution so that it pleases a wider audience, beyond those who have an immediate or technical interest in it.

In the last two decades of the broad development of the study of institutional work, analyses have focused on the incorporation of new forms of work that involve deliberate efforts to shape organizational facets. Research on institutional work aims to alter the view of social changes on a large scale, so that more attention is paid to the relations between institutions and the actors that form them. To do so, a holistic view of institutional action is required, which goes beyond dyadic relationships and assumes that actors are at times subject to the pressures of different institutions and often need to respond locally, with creativity and reflexivity. The questions become more related to understanding "why" and "how", instead of "what" and "when" (Lawrence et al., 2011).

In order to answer our research question, we mobilized the following aspects of the institutional work theory (see Table 1). 
Table 1

Aspects of the institutional work theory

\begin{tabular}{|c|c|c|c|}
\hline Institutional work & Subcategory & Details & How it was applied to our case \\
\hline Political & $\begin{array}{l}\text { Advocacy } \\
\text { Defining } \\
\text { Vesting }\end{array}$ & $\begin{array}{l}\text { Development of rules, property rights, and } \\
\text { limits referring mainly to the regulatory } \\
\text { pillar of institutions. }\end{array}$ & $\begin{array}{l}\text { Analysis of practices to define } \\
\text { governance for the cooperative } \\
\text { arrangement. }\end{array}$ \\
\hline Technical & $\begin{array}{l}\text { Constructing identities } \\
\text { Changing normative } \\
\text { associations } \\
\text { Constructing normative } \\
\text { networks }\end{array}$ & $\begin{array}{l}\text { Provides an institution with a degree } \\
\text { of rigor and ensures that the work can } \\
\text { be more easily transported from one } \\
\text { environment to another. }\end{array}$ & $\begin{array}{l}\text { Analysis of practices to define } \\
\text { rules of the cooperative } \\
\text { arrangement. }\end{array}$ \\
\hline Cultural & $\begin{array}{l}\text { Mimicry } \\
\text { Theorizing } \\
\text { Educating }\end{array}$ & $\begin{array}{l}\text { Presentation of an institution so that it } \\
\text { pleases a wider audience. }\end{array}$ & $\begin{array}{l}\text { Analysis of practices to spread } \\
\text { community identity. }\end{array}$ \\
\hline
\end{tabular}

Note. Adapted from "Institutions and institutional work “, by T. B. Lawrence \& R. Suddaby. In: S. R. Clegg, T. B. Hardy, \& W. R. Lawrence. Nord. Handbook of organization studies.

\section{I Cooperation as an institution}

One of the essential elements of institutional work is the definition and characterization of institutions. Institutional work emerges from the organizational approach to institutional theory. Firstly, it is important to acknowledge the notion of institutionalization presented by Selznick (1972). Institutionalization is a process that occurs in the organization over time, where the experiences and aspirations of people who work in it, besides the interests of small groups and society in general, begin to shape its performance. So, it is possible to define the institution itself as the enduring elements of social life that affect the behavior and beliefs of individual or collective actors by providing patterns for action, cognition, and emotion (Lawrence, Suddaby, \& Leca, 2009).

In order to properly enhance performance and achieve competitive goals, cooperative arrangements among organizational actors must have social patterns that shape action and interaction inside their boundaries. Thus, this organizational structure is understood as an institution.

Interorganizational cooperation may be defined as any agreement that establishes cooperation between actors. It occurs voluntarily and begins with actions that involve exchanging, sharing, or codevelopment (Gulati \& Gargiulo, 1999). It is cooperation between partners that crosses organizational boundaries (Nolte, Martin, \& Boenigk, 2012). In the process of interorganizational cooperation, two or more organizations cooperate to achieve common goals, while each organization's business decisions and actions remain autonomous (Balestrin \& Verschoore, 2016). As Balestrin and Verschoore (2016) emphasize (see Figure 1), coordination, the existence of common goals, and connectivity amongst members are essential for the achievement of collective results. 


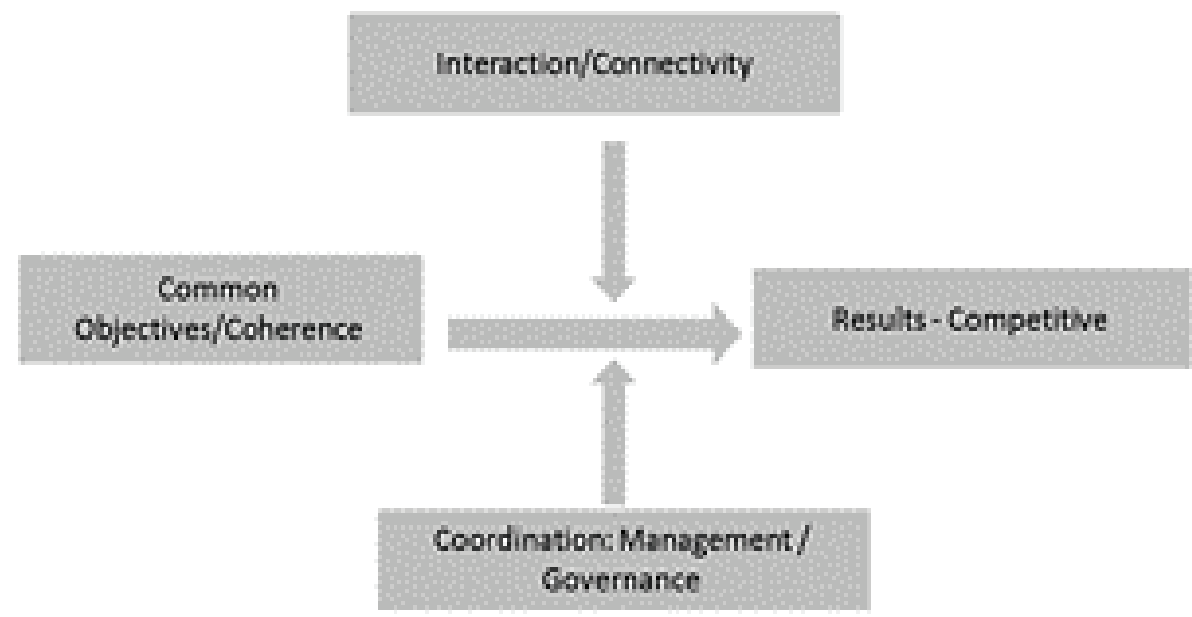

Figure 1. Conditions for the establishment of cooperation networks

Source: Adapted from "Redes de Cooperação Empresarial:

Estratégias de Gestão na Nova Economia”, by A. Balestrin \& J. Verschoore (2016).

We support the argument that the practices employed by social actors and institutional work create a network through the establishment of common objectives, interaction, and coordination, and this positively impacts local and regional development (Geddes, 2014), or competitive gains in business cases. In this collaborative model, the actors feel motivated to work towards legitimating a practice that is considered important to the social context (Lawrence \& Suddaby, 2006). These efforts are made by the people who create the institutions around them to meet their social needs (Styhre, 2014). The process of defining what will be developed as work aims to obtain positive results (Geddes, 2014).

In analyses that involve institutional work, the individuals become agents, so that relationships, behaviors, and motivations are directly linked to their interests and attention (Lawrence et al., 2011). In this sense, the resulting local development becomes essential to establish cooperation between organizations (Geddes, 2014), thus forming collaborative processes among social actors (Balestrin \& Verschoore, 2016).

\section{Methodology}

To address the proposed research problem, a single case was chosen. The case is from a unique social context, that of a community located in the Amazon region with little logistical infrastructure, surrounded by important environmental resources and home to diverse populations (indigenous people, extractivists, family farmers, public managers, managers of private organizations, and NGOs). It is the only settlement in the State of Mato Grosso with a legal reserve that is certified for extracting Brazil nuts.

The research consisted of three phases. The first was exploratory in nature and had the goal of identifying the main social actors in the collaborative arrangement found in the Amazon community. In this phase, one of the researchers lived for 25 days in this community, during which time he performed and recorded five formal interviews and had a set of informal conversations registered on 103 sheets of notes (in a field notebook). The researcher participated in collective activities such as meetings, social activities, courses, and seminars that occurred in the community. In addition to the interviews, he 
made an inventory of secondary data offered by the local actors. Several documents were analyzed: projects and reports (5), meeting reports (12), and institutional videos (13). This set of secondary data and the five primary interviews allowed the researchers to begin the reconstruction of the history, identifying the main actors. However, theoretical saturation was not obtained at this stage and we started to plan a new phase for data collection.

In the second phase of the research, we asked about the practices of individual and collective actors aiming towards the institutionalization of cooperation in the settlement, the main motivations for this action, and the day-to-day work obtained by the institutionalization of cooperation. The researchers then performed seven more interviews, which were also recorded, amounting to a total of 3:56:02 hours of recordings, and two email interviews to validate the perceptions collected during the researcher's time in the settlement. In the third phase, one of the researchers remained in the community for 10 more days to finalize the data collection. In addition to living the daily routine of the settlement, he participated in three meetings in the indigenous villages of the Murunduku, Caiaby, and Apiaká peoples. The questions that guided the research in all data collection phases were validated by 5 specialists. We stopped the data collection when no interviewee or secondary document provided new information related to the research objectives. "Retrospective research designs are particularly useful to study network processes and network evolution over large windows of time. This may be important to detect substantial changes in networks and the emergence of clear temporal patterns" (Provan, Fish, \& Sydow, 2007).

The data analysis began during the data collection. To develop a deeper understanding of the data and the underlying themes and patterns, first we used visual mapping with temporal bracketing strategies to guide our analysis and the data presentation. This option visualizes the complexity of creating an institution and searches for patterns. The organization of data into periods allows for an analysis of the effects of actors' motives and actions and the impact of the context of one period on another. Time periods were chosen based on key actors' subjective interpretations of milestone events during the transformation process. Temporal bracketing allowed us to follow the process of transformation through time and evaluate the result of each phase in the form of institutionalization of cooperation. The reconstruction of the history and the visual map were based on the primary and secondary data that were collected.

We used a number of techniques to ensure research reliability, based on Lincoln and Guba (1985), such as: a) Credibility: the researcher had involvement in the field; b) Transferability: a description of the context of the AVA settlement was provided, which enabled an understanding of the reality experienced by the set of actors; c) Dependability: we used theoretical and intentional sampling, as described in this section; and d) Confirmability: there was careful management of the data.

\section{The Settlement's History and Presentation of the Main Cooperation Network}

From the data collection performed, we reproduced the history of the creation of the institutional cooperation in the form of an interorganizational network. In the map (see Figure 2) and in the interviews (see Table 2 for some key excerpts), it is possible to find the main motivations of the actors undertaking institutional work practices and the way the network of actors is formed as the work evolves. It shows "institutions and action as existing in a recursive relationship [...] in which institutions provide templates for action [...] and action affects those templates" (Archer, 1995; Phillips, Lawrence, \& Hardy, 2004). 
Table 2

\section{Key Excerpts from the Interviews - Main Motivations}

Interviewee
Empirical Evidence
"... the main objective of COOPAVAM was to protect the legal reserve. COOPAVAM was born for this [...] and also for
the construction of the Brazil nut factory. The factory always meant an alternative for income generation."
"... what motivated the activities in the "Vale do Amanhecer" was the construction of a family agriculture area [...]
a settlement born with the possibility of developing long-term work with a whole socio-environmental vision for the
community."
"... the number of families involved in the oil chain [...] being in the Amazon and having the only registered settlement of
the state of Mato Grosso."
"this was the opportunity to prioritize the people of the community. INCRA always talked about this - you must start an
association to give work to the people here"
"... the Brazil nut project collaborates and fits with the ideas of FUNAI - the importance of this link is enormous, I don't
know how to explain it..."
"He even convinced INCRA that if he provided support with part of the resources for the project of creating the factory, it
would be also helping to maintain the legal reserve [...] Why is it important? Because, it is the reserve that was going to
produce the Brazil nuts for the factory."

The creation of rural settlements in Brazil began in 1998. They were created in national territory under a program called "New Rural World". A rural settlement is a set of agricultural units that are independent from each other, established by the National Institute of Colonization and Land Reform (INCRA). Each lot is given over by the INCRA to a family that cannot afford to acquire and maintain a rural property by other means. Rural workers who receive a lot commit to living on the land and exploiting it for sustenance using only family labor. In addition to land distribution, rural reform settlements provide living and production conditions and guarantee the health and safety of those living in rural zones, who previously found themselves under food safety and social risks. The "Vale do Amanhecer Settlement Project" (AVA) is one of the 371 settlements created by the federal program and is considered a role model for the Amazon region (INCRA/SR-13/T, 1996; United Nations, 2006).

The settlement is located in the town of Juruena, in the northeast of Mato Grosso state. It is a rural community of $14,715.81$ ha, divided into 250 lots for economic subsistence and for living on. In this settlement, "all the roads are parallel to the small tributaries of the Juruena River, so that everyone has running water at the back of their land.
This settlement structure may make a difference in relation to wildlife preservation" (Interviewee 9). This manner of demarcating properties was a topic of debates and discussions among those living in the region, local political representatives, and other organizations interested in the preservation of the Amazon region. All the settlement activities and collaborative agreements presented in this study are linked to the exploitation of the Brazil nut.

The history of the creation and development of AVA is linked to the history of a partner association, the Association of Rural Development of Juruena (ADERJUR). This association was founded in the town of Juruena in 1994 with the aim of providing income to the local family farmers and promoting environmental preservation through the sustainable management of natural resources, the development of awareness, and capacity-building activities for the farmers (Nunes \& Rugnitz, 2011). The first project of local relevance ADERJUR participated in was the creation of AVA in 1996. In the definition of the AVA settlement project, local actors were required to establish partnerships to evaluate social and legal aspects.

After the creation of the settlement, ADERJUR consolidated itself as the proponent 
and executor of projects for local development through sustainable productive practices in the region. Many of these projects were proposed in favor of AVA's rural community and local indigenous communities. In the words of one of the participants, “... what motivated ADERJUR to enter the Vale do Amanhecer first was the fact that it had the documentation for the land, which was an area of family farming, a settlement with the possibility of developing a long-term project with a socio-environmental perspective geared towards the community [...] we were able to achieve several things, to maintain these families living on the land..." (Interviewee 9).

AVA's settlement project ended in 2008, and soon the need was recognized to search for alternatives to strengthen economic and social aspects of the labor force. This led to the establishment of the Cooperative of the Rural Producers of Vale do Amanhecer (COOPAVAM), which represents "a milestone for AVA to become a reference model of sustainable productivity" (Interviewee 9) because it is a popular initiative of cooperation in partnership with indigenous communities.

Among AVA's participating actors are important governmental entities such as the National Supply Company (CONAB) and the State Environment Department (SEMA$\mathrm{MT})$. CONAB is responsible for supporting rural producers in the elaboration of projects for food sales. It also assists the cooperative with information and instructions on how to directly purchase food products with public funds and is therefore an important partner of COOPAVAM. SEMA-MT is a department that grants authorizations to perform economic industrial activities in rural areas. Furthermore, "CONAB buys the products that COOPAVAM makes - nuts, the derivative of nuts, oil, flour and they are distributed in schools. Now we are working with seven towns here around Jurema" (Interviewee 8).

The city government, represented by the City Hall of Juruena-MT, has a close relationship with COOPAVAM and is motivated by the exchange of benefits. It "is motivated to be in the partnership because the work performed provides income to the inhabitants and allows the acquisition of products to supply schools and hospitals with resources from other government departments, which reduces administrative costs" (Interviewee 10). According to the representative of the city hall, "The work performed by AVA began in approximately 2007-2008, the period when the gold-digging activity occurred, aggravating local violence [...] with the town's history, developing organizations which may create formal employment makes the difference for economic and social development" (Interviewee 10).

AVA receives resources from projects submitted by COOPAVAM and the Cantinho da Amazônia Women's Association (AMCA) through public bidding documents. The main funding agencies are Petrobras and Banco da Amazônia, which work as co-financing partners for activities to meet social goals. AMCA, an enterprise born within COOPAVAM, emerged due to gender and workplace conflict. However, there is currently an exchange of work between enterprises, division of resources in projects submitted to development agencies, and division of space within the industrial area of the settlement. 

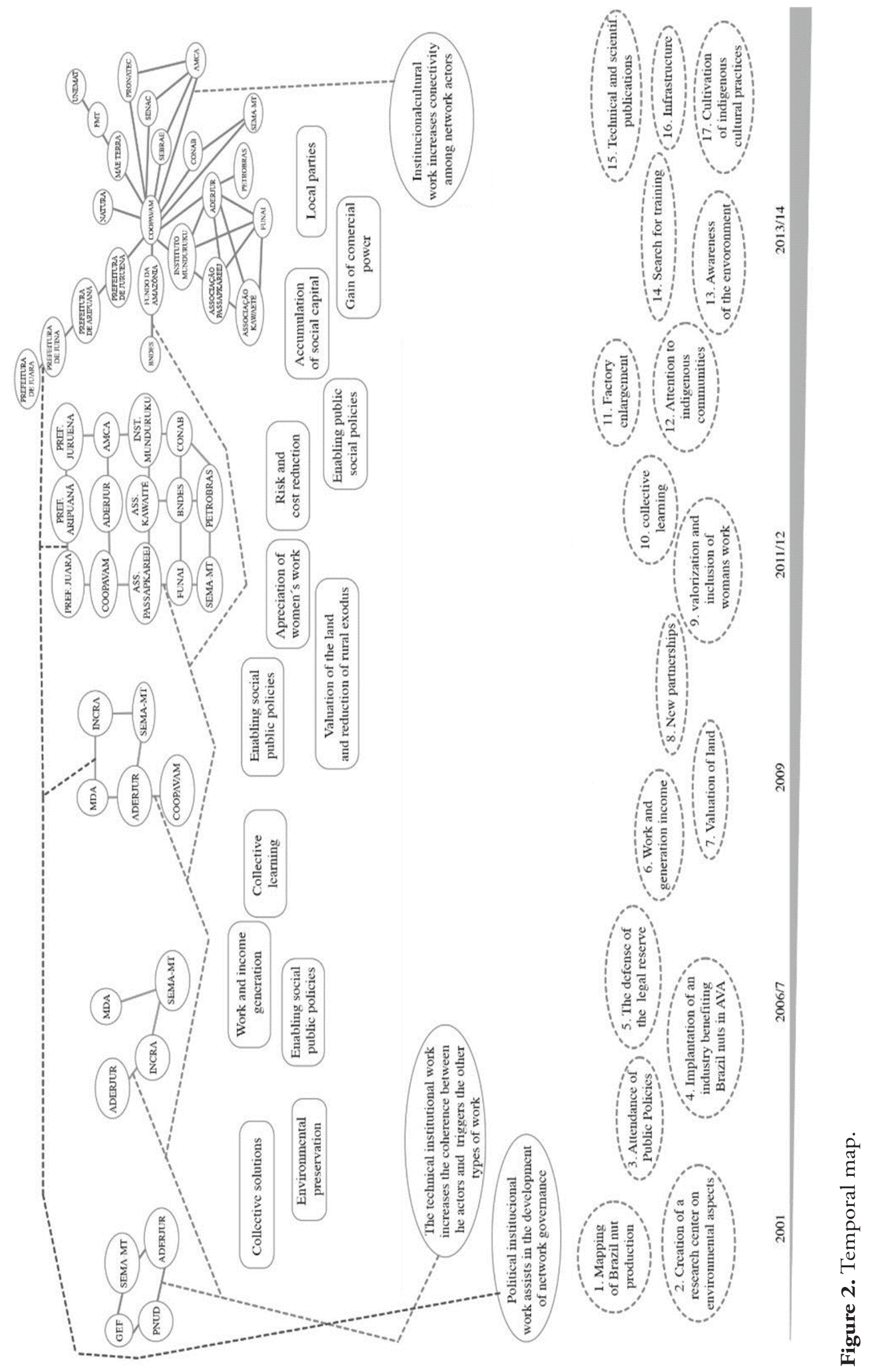
One of the important public agencies that shows the greatest ties and commitment in carrying out daily activities in AVA is the National Indian Foundation (FUNAI). When proposing a project, such as harvesting and selling the Brazil nuts from the indigenous villages to COOPAVAM, FUNAI's participation and logistical support is required to develop meetings, seminars, followups of economic and social results, and the monitoring of environmental issues. FUNAI's technicians are important communication links between the indigenous people and the members of the AVA/ COOPAVAM settlement.

The indigenous associations ACAIM, Passapkareej, Kawaieté, and Instituto Munduruku also have a close relationship. The role of the representatives of indigenous associations is to mediate the dialogue between indigenous workers and COOPAVAM with the communities, organize the reception and sale of the nuts, and distribute the resources received among the indigenous people who work in the extraction of the product. The relationship with the leadership of the indigenous associations is fundamental for the maintenance of collaboration projects, as access to the product occurs through the association. Clear and transparent communication is required. All these activities are monitored by FUNAI by law. Natura Cosmetics (one of the main cosmetics companies in Brazil) is motivated to develop activities with COOPAVAM and "to be part of the collaborative arrangement because the work developed in the settlement has social relevance and is legalized, which favors the partnership and allows the company to contribute and benefit, as it acquires quality products and certificates. On the other hand, COOPAVAM benefits from contracts properly negotiated in a participatory manner, receiving training in organizational management, health, and worker safety" (Interviewee 1).

As evidence of the institutionalization of cooperation in the settlement, a series of joint activities may be highlighted. The oldest initiative was the project "Conservation and Sustainable Use of Biodiversity in the Border
Forests in Northwest Mato Grosso", developed in 2001 through collaboration between Global Environment Facility (GEF), PNUD, and SEMAMT in 2001. Among the main products of this project are the mapping of Brazil nuts and the feasibility analysis of extractive production (Nunes \& Rugnitz, 2011).

In 2006, the project called "Recovery and Conservation of Natural Resources" was proposed in the Vale do Amanhecer Settlement Project, in Juruena/MT, in which the Ministry of Agrarian Development (MDA) and INCRA acted as supporters for the development of the on-site project ADERJUR. Then, in 2007, MDA, INCRA, and ADERJUR had a meeting about the implementation of the COOPAVAM plant for processing the Brazil nuts. In 2009, the "Inventory Training Program" and "Purchase with Donation Program" of Companhia Nacional de Abastecimento (CONAB) were established as formal partnerships between CONAB and COOPAVAM (Nunes, 2013; Nunes \& Rugnitz, 2011).

Two projects gave the most visibility to the community in the national media. The first was the Carbon Well Project, built collectively with the social groups and submitted to ADERJUR. This project had two editions, with the first proposal submitted in 2009 and starting its operations in 2010 and the second proposal submitted in 2012 to continue the activities in 2013. The main objectives were: a) to plant an agroforestry system; b) to raise farmers', teachers', and students' awareness of the need to recover degraded areas; c) to stimulate the conservation of remaining forest; d) to develop extractive activities of non-timber forest products, which include the Brazil nuts; and e) to seek ways to promote food safety and income generation for the communities and climate stability. The main partners of the projects financed by Petrobras were ADERJUR, COOPAVAM, FUNAI, Munduruku Institute, $\mathrm{CONAB}$, Banco do Brasil Foundation, and the municipal governments of Juruena-MT, Juína, Juara, and Aripuanã. It is worth noting 
that the municipal governments of the towns near Juruena participated in the partnership through advertising and acquiring products produced by AMCA to meet the food demands of kindergartens, schools, hospitals, and nursing homes (Nunes \& Rugnitz, 2011).

In 2013, the Sentinelas da Floresta (Forest Guardians) Project was submitted to Banco da Amazônia, which also contributed significantly with financial support ( $\mathrm{R} \$ 5.5$ million). This project had the following main actors: COOPAVAM as the proponent and the Amazon Fund as a funder. It also included ADERJUR and other partners involved in the project's execution: indigenous associations (Passapkareej, Instituto Munduruku, and Associação Kawaieté), FUNAI, CONAB, Natura, Mãe Terra, and the Municipal Government of Juruena. The main objective was to increase the scale of production and strengthen the production chain for the Brazil nuts, from collection and processing to commercialization, increasing the income of the extractive communities living on the region's forest products (Nunes, 2013).

Throughout the settlement's development process, several higher education institutions and research institutes were present. During the research phase, the State University of Mato Grosso (UNEMAT) and the Federal University of Mato Grosso (UFMT) developed research and extension activities in the AVA community. Other partner institutions in the training process were SEBRAE, SENAC, and PRONATEC. In 2015, there was expansion of the Brazil Nut Production Unit in Juruena/MT, a complementary project to Sentinelas da Floresta, and a collaborative action between the Amazon Fund, the National Bank for
Economic and Social Development (BNDES), and COOPAVAM.

After the beginning of COOPAVAM's activities and the projects in the region, the number of partners increased gradually, consolidating work practices seeking cooperation. The partners are not permanent. Some have formal commitments with cooperation contracts, while others are informally engaged in the activities developed in AVA as demanded by project actions, population needs, legal aspects, or other factors due to work dynamics and the social life of the community. Cooperation occurs through temporary collaborative projects that have a beginning, middle, and end. In this sense, it is possible to say that there has been institutionalization of cooperation given that projects have emerged as alternative solutions to the issues faced by the community and its members. The partnerships have continued in dyads and triads. Dyads occur frequently between COOPAVAM and the other partners, whereas triads are established when the assistance of a regulatory or supervisory organization (e.g., FUNAI) is required. Once we identified the main social actors in the settlement, we sought to identify the main motivations for institutional work that are linked to cooperation.

\section{I Discussion of Results}

\section{I. I Motivations for the institutionalization of cooperation}

To facilitate the presentation of the main motivational factors for institutional work practices, Table 3 highlights some empirical evidence obtained in this study. 
Table 3

\section{Motivational factors for institutional work}

\begin{tabular}{ll}
\hline $\begin{array}{l}\text { Motivational } \\
\text { Factors }\end{array}$ & $\begin{array}{l}\text { This is motivating because } \\
\text { cooperation could... }\end{array}$ \\
\hline & offer services, products, and \\
$\begin{array}{l}\text { Generation } \\
\text { of collective } \\
\text { solutions }\end{array}$ & $\begin{array}{l}\text { collective infrastructure for the } \\
\text { development of its associates } \\
\text { (Balestrin \& Verschoore, 2016). }\end{array}$
\end{tabular}

\section{Empirical Evidence}

"...we worked as a group on an assignment regarding the cooperative's organizational management...” (Interviewee 3). “... we brought in two new buyers of nuts..." (Interviewee 1). "This is because the forest guardians project built several large tents, which was something that was difficult..." (Interviewee 7).

"It is a joint investment, we always do it for the best price" (Interviewee 7). "Regarding Incra's investment [...] with part of

Risk and cost share the costs of investments reduction (Balestrin \& Verschoore, 2016). the funds for the factory creation project, it would be helping to maintain the legal reserve, in addition to recovering some areas and in the least amount of time, keeping the reserve ..." (Interviewee I2).

"... several people see this union and find it beautiful, this exchange

Accumulation of social capital

increase social relationships and friendship bonds that go beyond economic aspects.

\begin{tabular}{ll}
\hline $\begin{array}{l}\text { Collective } \\
\text { learning }\end{array}$ & $\begin{array}{l}\text { enable access to different types of } \\
\text { knowledge and ideas (Balestrin \& } \\
\text { Verschoore, 2016). }\end{array}$ \\
\hline $\begin{array}{l}\text { Gaining } \\
\text { commercial } \\
\text { power }\end{array}$ & $\begin{array}{l}\text { promote representativeness, } \\
\text { credibility, and legitimacy in the } \\
\text { market. }\end{array}$ \\
\hline $\begin{array}{l}\text { Work and } \\
\text { income }\end{array}$ & $\begin{array}{l}\text { foster initiatives that offer } \\
\text { opportunities in the institutional } \\
\text { context. }\end{array}$
\end{tabular}

\begin{tabular}{ll}
$\begin{array}{l}\text { Collective } \\
\text { learning }\end{array}$ & $\begin{array}{l}\text { enable access to different types of } \\
\text { knowledge and ideas (Balestrin \& } \\
\text { Verschoore, 2016). }\end{array}$ \\
\hline $\begin{array}{l}\text { Gaining } \\
\text { commercial } \\
\text { power }\end{array}$ & $\begin{array}{l}\text { promote representativeness, } \\
\text { credibility, and legitimacy in the } \\
\text { market. }\end{array}$ \\
\hline $\begin{array}{l}\text { Work and } \\
\text { income } \\
\text { generation }\end{array}$ & $\begin{array}{l}\text { foster initiatives that offer } \\
\text { opportunities in the institutional } \\
\text { context. }\end{array}$
\end{tabular}

Work and foster initiatives that offer income opportunities in the institutional generation context.

of ideas" (Interviewee 5). "It is really personal, dedication, it's rooting for the people who are there. I say that in the cooperative we are a family, you see?” (Interviewee 3).

"...with this training, with these courses there is digital inclusion, there are people in the cooperative that also do it." (Interviewee 3). "Now, we had two courses offered by Natura. They are helping, one was on work safety, one on first aid..." (Interviewee 5).

"We work as partners, purchasing nut and almond oil. We work with a fair price in a positive way - win-win” (Interviewee 1). "...having the only settlement in the state of Mato Grosso properly registered. (Interviewee 1).

"there are people whose income comes from the cooperative, so imagine the importance it has" (Interviewee 3). "...my dream is to see this continue and that it works all year round so no one becomes unemployed".

"...the project had two clear goals, one was the recovery of some promote debates on the needs areas, a hectare per family, something like that, with planting of Environmental of the environment and its preservation importance to the sustenance and maintenance of the settlement. forest systems according to a proposal previously discussed with farmers from there, and the other was the construction of the factory for a group of families that worked on the extraction of the nuts." (Interviewee 9).

\begin{tabular}{|c|c|c|}
\hline $\begin{array}{l}\text { Appreciation of } \\
\text { women's work }\end{array}$ & $\begin{array}{l}\text { offer opportunities for women to } \\
\text { be recognized in organizational } \\
\text { activities. }\end{array}$ & $\begin{array}{l}\text { "The main reason for women to work in the association is the } \\
\text { income" (Interviewee 5). }\end{array}$ \\
\hline $\begin{array}{l}\text { Valuation of } \\
\text { the land and } \\
\text { reduction of } \\
\text { rural exodus }\end{array}$ & $\begin{array}{l}\text { promote opportunities for young } \\
\text { people to remain in agriculture. }\end{array}$ & $\begin{array}{l}\text { "What I want, and I mean myself, because I think of the young } \\
\text { people. I am working with the boys, we even wrote a project... } \\
\text { (Interviewee 9). "...I think it is interesting to begin with the young } \\
\text { people's participation [... I I want to engage them to continue what } \\
\text { we have done." (Interviewee 5). }\end{array}$ \\
\hline $\begin{array}{l}\text { Enabling social } \\
\text { public policies }\end{array}$ & $\begin{array}{l}\text { promote the success of public } \\
\text { policies related to social inclusion. }\end{array}$ & $\begin{array}{l}\text { "They generate income for many families, it was even recognized } \\
\text { internationally for its arrangement and history." (Interviewee 1). }\end{array}$ \\
\hline
\end{tabular}


As we see in Table 3, our results corroborate the argument that social actors feel motivated and intentionally make efforts to create and maintain a new social reality in regard to vulnerability (Lawrence \& Suddaby, 2006). There must be one or more reasons for the existence of work practices. In our case such reasons are manifold (e.g. income generation, environmental preservation, commercial leverage etc.). Rationality assumes that social actors have the capacity to reflect on their beliefs and give attention to actions that change the daily lives of individuals (Schildt, Mantere, \& Vaara, 2011). Intentionality and motivation begin with social actors who reflect on their social responsibility, living conditions, and desires for change and/or social transformation (Lawrence, Leca, \& Zilber, 2013). Thus, in the social context of our case, agents emerge that individually or collectively want to build new institutional forms. Practices are therefore no longer just what people do, seeking to meet social expectations (Whittington, 2006).

In AVA's social reality, it is noteworthy that different actors worked with the purpose of creating a new institution capable of guaranteeing an improvement in the quality of life in the settlement.

In this social context, the motivation of social actors emerges to transform the local reality. It is the people who create institutions to meet societal needs (Styhre, 2014). Purposeful actions influence the institutionalization of practices (Hwang \& Colyvas, 2011). People's motivations are the starting point for understanding behavior and action. Hence, the central axis of institutional work focuses on the strategic and everyday practices that individuals or groups of individuals intentionally undertake (Dover \& Lawrence, 2010). Social actors become the driving force seeking improvements in the environment in which they live. They aim to transform their condition of social vulnerability.

\section{I.2 Institutional work and cooperation}

The main technical work practices identified are listed in Table 4.

Table 4

\section{Practices of technical institutional work}

\begin{tabular}{|c|c|c|c|}
\hline & Practice description - technical work & $\begin{array}{l}\text { Evidence } \\
\text { (excerpts from interviews) }\end{array}$ & $\begin{array}{l}\text { Impact on the creation of the } \\
\text { institution }\end{array}$ \\
\hline 1.1 & Project submission & Access to various projects (secondary data) & It forces collective thinking \\
\hline 1.2 & $\begin{array}{l}\text { Borrowing raw materials and exchange } \\
\text { of labor among AVA's enterprises. }\end{array}$ & $\begin{array}{l}\text { "Right now, we had two courses offered by Natura. } \\
\text { They are helping. One was on safety at work and } \\
\text { the other on first aid" (Interviewee 1) } \\
\text { "...even with training courses on good food } \\
\text { production practices, it is necessary to inspect." } \\
\text { (Interviewee 11) }\end{array}$ & $\begin{array}{l}\text { It strengthens the relationships } \\
\text { among the partner enterprises } \\
\text { established in AVA. }\end{array}$ \\
\hline 1.3 & $\begin{array}{l}\text { Community garden in the indigenous } \\
\text { areas and in other communities. }\end{array}$ & $\begin{array}{l}\text { Report on the dissemination of the results of the } \\
\text { Sentinelas da Floresta project ( } 1^{\text {st }} \text { edition), visit in } \\
\text { loco, and images (secondary data). }\end{array}$ & $\begin{array}{l}\text { It expands community } \\
\text { relationships and benefits food } \\
\text { subsistence. }\end{array}$ \\
\hline 1.4 & $\begin{array}{l}\text { Technical courses with the } \\
\text { community's participation (digital } \\
\text { inclusion; workshops on nut } \\
\text { processing and use of fruits, vegetables } \\
\text { and devitalized wood, etc.). }\end{array}$ & $\begin{array}{l}\text { "Right now, we had two courses offered by Natura. } \\
\text { They are helping. One was one on safety at work } \\
\text { and the other on first aid" (Interviewee 1) } \\
\text { "... with training courses on good food production } \\
\text { practices..." (Interviewee 11) }\end{array}$ & $\begin{array}{l}\text { It expands social relations } \\
\text { and spaces to socialize the } \\
\text { competencies acquired at work } \\
\text { daily. }\end{array}$ \\
\hline
\end{tabular}




\begin{tabular}{|c|c|c|c|}
\hline & Practice description - technical work & $\begin{array}{l}\text { Evidence } \\
\text { (excerpts from interviews) }\end{array}$ & $\begin{array}{l}\text { Impact on the creation of the } \\
\text { institution }\end{array}$ \\
\hline 1.5 & $\begin{array}{l}\text { Exchange of experiences among } \\
\text { other organizations, excursions to } \\
\text { the community to learn about what } \\
\text { is developed at AVA (schools, other } \\
\text { organizations, public administrators, } \\
\text { students, etc.). }\end{array}$ & $\begin{array}{l}\text { Report on the dissemination of the results of } \\
\text { the Sentinelas da Floresta project }\left(1^{\text {st }} \text { and } 2^{\text {nd }}\right. \\
\text { editions) (secondary data) }\end{array}$ & $\begin{array}{l}\text { It promotes experience and } \\
\text { brings prospective partners. }\end{array}$ \\
\hline 1.6 & $\begin{array}{l}\text { Field days with the community in } \\
\text { areas of extractivism or vegetable } \\
\text { gardening and planting of seedlings. }\end{array}$ & $\begin{array}{l}\text { Report on the dissemination of the results of } \\
\text { the Sentinelas da Floresta project ( } 1^{\text {st }} \text { and } 2^{\text {nd }} \\
\text { editions) (secondary data) } \\
\text { Project submitted in partnership with the } \\
\text { university (UNEMAT) on Environmental } \\
\text { Education (secondary data). }\end{array}$ & $\begin{array}{l}\text { It promotes the exchange of } \\
\text { experience and reflections } \\
\text { between members of the } \\
\text { community. }\end{array}$ \\
\hline 1.7 & $\begin{array}{l}\text { Submission of projects to compete for } \\
\text { awards offered by support agencies. }\end{array}$ & $\begin{array}{l}\text { Millennium Development Goals Award - ODM } \\
\text { BRAZIL (2013). Website: <http://www.ipea. } \\
\text { gov.br/desafios/index.php?option=com_content } \\
\text { \&view=article\&id=2966:catid=28\&Itemid=23> } \\
\text { Banco do Brasil Foundation Award for AMCA } \\
\text { in 2014. Website: https://www.cidadenova. } \\
\text { org.br/editorial/inspira/577-mulheres_ } \\
\text { impulsionam_geracao_de_renda_no (secondary } \\
\text { data) }\end{array}$ & $\begin{array}{l}\text { It improves the community's } \\
\text { knowledge on the work } \\
\text { developed at AVA and its } \\
\text { benefits. }\end{array}$ \\
\hline 1.8 & $\begin{array}{l}\text { External professionals' technical } \\
\text { work as support to the enterprises } \\
\text { (COOPAVAM; AMCA, four native } \\
\text { associations). }\end{array}$ & $\begin{array}{l}\text { "Then these reports from visits by each technician, } \\
\text { in each property, every day, are inserted in the final } \\
\text { report with the signatures of all those involved." } \\
\text { (Interviewee 2) }\end{array}$ & $\begin{array}{l}\text { This practice occurs while there } \\
\text { are projects being sponsored. } \\
\text { However, it improved the } \\
\text { enterprises' knowledge and } \\
\text { workers' learning. }\end{array}$ \\
\hline 1.9 & $\begin{array}{l}\text { Promotion of events to raise awareness } \\
\text { of the environment in public schools. }\end{array}$ & $\begin{array}{l}\text { Report on the dissemination of the results of } \\
\text { the Sentinelas da Floresta project ( } 1^{\text {st }} \text { and } 2^{\text {nd }} \\
\text { editions) (secondary data) } \\
\text { Project submitted in partnership with the } \\
\text { university (UNEMAT) on Environmental } \\
\text { Education (secondary data). }\end{array}$ & $\begin{array}{l}\text { It raises the community's } \\
\text { awareness of environmental } \\
\text { issues and the value of the work } \\
\text { developed in the region. }\end{array}$ \\
\hline 1.10 & $\begin{array}{l}\text { Master theses and doctoral } \\
\text { dissertations on the case: CATIE } \\
\text { - Centro Agronómico Tropical de } \\
\text { Investigación y Enseñanza (Costa } \\
\text { Rica); POLICYMIX (Norway); } \\
\text { Federal University of Mato Grosso, } \\
\text { State University of Mato Grosso, and } \\
\text { Federal University of Goiás (Brazil) }\end{array}$ & $\begin{array}{l}\text { "...currently the experience here in the state of } \\
\text { Mato Grosso draws attention from academia, } \\
\text { including studies of foreign universities such as } \\
\text { CATIE and POLICYMIX, as well as works by } \\
\text { UFMT and UNEMAT" (Interviewee 2) }\end{array}$ & $\begin{array}{l}\text { It offers analyses from different } \\
\text { viewpoints on the experience, } \\
\text { which may contribute to the } \\
\text { replication of social innovation } \\
\text { practices. }\end{array}$ \\
\hline 1.11 & $\begin{array}{l}\text { Exhibition of the products in national } \\
\text { and international fairs. }\end{array}$ & $\begin{array}{l}\text { Evidence on COOPAVAM's institutional } \\
\text { website (secondary data) }\end{array}$ & $\begin{array}{l}\text { It improves product } \\
\text { commercialization and } \\
\text { knowledge on other experiences. }\end{array}$ \\
\hline
\end{tabular}

Our results confirm that interorganizational cooperation is a relevant behavior for the development of communities that live in situations of social vulnerability, as actions emerge such as meeting social needs, promoting new forms of thinking, and creating partnerships between governmental departments (Gyapong, Selby, \&
Anakwah, 2011), in addition to partnerships seeking local and regional development that frequently include actors from the community, civil society, and formal for-profit and nonprofit public organizations (Geddes, 2014).

The daily dynamics of institutional work in the AVA settlement is complex because 
it involves social actors living in different contexts in the productive activities that form the interorganizational cooperation. The efforts of the natives occur through extractive work, among their peers and within a cultural context of their own. However, work efforts in the areas of the settlement occur in different cultural contexts, considering the workers' different origins. In addition, there are social actors that are external to these environments, who are part of public and private organizations and NGOs, whose work practices seek resources to meet the demands of previous social groups. Thus, finding synchronicity between all these actors and performing work practices that meet the common goal of changing the local reality through cooperation is a challenging task. The complexity of the work occurs mainly in production environments. Although the common goal is clear, individually and in daily work actions, workers do not always understand the interdependence of activities, either internally or externally. For these differences to be respected and understood, people must pay attention to external actors who propose changes in the social context of vulnerability based on promotion projects and the search for possibilities for the institutionalization of cooperative activities.

This reality has contributed to reflections in contexts of complex social problems, as presented by Dover and Lawrence (2010), who highlight the need for social actors to be constantly acting in negotiations that involve contestation and cooperation (Zilber, 2007). These negotiations have occurred mainly between the rural and indigenous communities because some of those cooperating and many natives do not understand the bureaucracy of project management but instead prioritize their groups' individual needs to the detriment of what was collectively agreed in the projects. Constant negotiations are coordinated by the project manager, technicians, and even partners who work in the courses offered to the communities, which promote the integration of work practices among the various social actors, as noted by Zietsma and Lawrence (2010).

The construction of the theoretical background revealed that institutional work may be classified as political, technical, and cultural (Zietsma \& Lawrence, 2010).

By identifying the technical work's contribution to the creation of the institution, it was verified that it increases the coherence between the partners of the network in formation. That is, the various technical works developed by the actors in this community have helped to define common objectives. The technical institutional work, insofar as it helps in the definition of the common objectives of the collaborative arrangement, constitutes the antecedents of the other technical work and facilitates the emergence of an environment of cooperation representing the interests of all the participants (Balestrin \& Verschoore, 2016). As political institutional work, which influences the rules, property laws, and limits and represents the regulating pillar of the institutions, the following practices presented in Table 5 were identified: 
Table 5

Political work practices

\begin{tabular}{|c|c|c|c|}
\hline & $\begin{array}{l}\text { Practice description - political } \\
\text { work }\end{array}$ & $\begin{array}{l}\text { Evidence } \\
\text { (excerpts from interviews or } \\
\text { secondary data) }\end{array}$ & $\begin{array}{l}\text { Impact on the creation of the } \\
\text { institution }\end{array}$ \\
\hline 2.1 & $\begin{array}{l}\text { Announcement of monthly balance } \\
\text { on the cooperative's bulletin boards. }\end{array}$ & $\begin{array}{l}\text { Experienced by the researcher during } \\
\text { insertion in the field in February } 2015 \\
\text { and through access to minutes of } \\
\text { meetings (observation and secondary } \\
\text { data). }\end{array}$ & $\begin{array}{l}\text { It broadens the management's } \\
\text { transparency and consequently offers } \\
\text { more tranquility to the relationship } \\
\text { between operational and bureaucratic } \\
\text { labor. }\end{array}$ \\
\hline 2.2 & $\begin{array}{l}\text { Offering local seminars on the } \\
\text { results of the projects and training } \\
\text { and information activities developed } \\
\text { in the region. }\end{array}$ & $\begin{array}{l}\text { Report on the dissemination of } \\
\text { the results of the Sentinelas da } \\
\text { Floresta project ( } 1^{\text {st }} \text { and } 2^{\text {nd }} \text { editions) } \\
\text { (secondary data). }\end{array}$ & $\begin{array}{l}\text { It expands the advertisement of the } \\
\text { activities, and the community gains } \\
\text { more knowledge on work practices. }\end{array}$ \\
\hline 2.3 & $\begin{array}{l}\text { Division of the benefits and } \\
\text { fostering more entrepreneurial } \\
\text { activities in projects. }\end{array}$ & $\begin{array}{l}\text { "...the ADERJUR truck helped } \\
\text { a lot in the beginning and it was } \\
\text { with this initial support from } \\
\text { ADERJUR that COOPAVAM [...] } \\
\text { could be developed. Collaboration, } \\
\text { loans, division of earnings, and } \\
\text { collective work were fundamental." } \\
\text { (Interviewee 2) }\end{array}$ & $\begin{array}{l}\text { Practice that promotes greater } \\
\text { relationships between the enterprises } \\
\text { that are part of the collaborative } \\
\text { arrangement. }\end{array}$ \\
\hline 2.4 & $\begin{array}{l}\text { Definition of the public that } \\
\text { benefits from the projects of AVA's } \\
\text { enterprises. }\end{array}$ & $\begin{array}{l}\text { Bylaws of COOPAVAM and AMCA } \\
\text { (secondary data). }\end{array}$ & $\begin{array}{l}\text { Through this practice, only AVA's local } \\
\text { members are allowed to work in AVA's } \\
\text { enterprises. }\end{array}$ \\
\hline 2.5 & Searching for new partners. & $\begin{array}{l}\text { "Partnerships are always welcome." } \\
\text { (Interviewee 1). } \\
\text { Period of experience - participation in } \\
\text { meetings. } \\
\text { Documentary research using the } \\
\text { COOPAVAM minutes. }\end{array}$ & $\begin{array}{l}\text { Constant practice where there is the } \\
\text { possibility of other organizations } \\
\text { assisting in problem-solving or } \\
\text { presenting new possibilities. }\end{array}$ \\
\hline 2.6 & $\begin{array}{l}\text { Creation of a managerial } \\
\text { council with representatives } \\
\text { of the enterprises that receive } \\
\text { support from the collaborative } \\
\text { arrangement and technicians } \\
\text { who work on the projects, with } \\
\text { meetings every three months. }\end{array}$ & $\begin{array}{l}\text { Report on the dissemination } \\
\text { of the results of the Sentinelas } \\
\text { da Floresta project ( } 1^{\text {st }} \text { edition) } \\
\text { (secondary data). }\end{array}$ & $\begin{array}{l}\text { It gives more transparency to the } \\
\text { activities developed in the projects. }\end{array}$ \\
\hline
\end{tabular}

Political work is the most present aspect in the context of work practices to foster partnerships for cooperation. This type of work is closely linked to the structure and coordination of the actors involved and helps in the development of an important element of the network: governance. The focus of network governance involves the use of structures to coordinate and control joint action (Provan \& Kenis, 2007), as we can see in the column for the impact of practices under the institution. In our view, the political work helps the institutionalization of the institution's "cooperation" because it helps create governance mechanisms for the actors. The political work is closely linked to the coordination of the network in formation. Shared governance networks consist of groups of organizations that work collectively. Finally, cultural work promotes work activities that identify the social groups through the development of practices valuing the group's 
setting. In this sense, in AVA, they sought to perform productive processes with regional products, support activities belonging to the local culture such as extraction of forest products, and promotion and appreciation of the activities. The main cultural work practices are presented in Table 6.

Table 6

\section{Institutional cultural work practices}

\begin{tabular}{|c|c|c|c|}
\hline & Practice description - cultural work & $\begin{array}{l}\text { Evidence } \\
\text { (excerpts from interviews) }\end{array}$ & $\begin{array}{l}\text { Impact on the creation of the } \\
\text { institution }\end{array}$ \\
\hline 3.1 & $\begin{array}{l}\text { Publications and local, regional, and } \\
\text { national TV appearances; central link's } \\
\text { website (COOPAVAM). }\end{array}$ & $\begin{array}{l}\text { Institutional webpage } \\
14 \text { audiovisual materials on YouTube; } \\
7,060 \text { results on Google (secondary } \\
\text { data) }\end{array}$ & $\begin{array}{l}\text { It promotes experience and values the } \\
\text { community. }\end{array}$ \\
\hline 3.2 & $\begin{array}{l}\text { Sale of produce in and by the community } \\
\text { to public departments, the municipal } \\
\text { education department, the welfare } \\
\text { department, schools, philanthropic } \\
\text { institutions, etc. }\end{array}$ & $\begin{array}{l}\text { "...including the Brazil nuts that came } \\
\text { from the indigenous lands, from the } \\
\text { settlements inside the factory so that the } \\
\text { Brazil nuts could go onto the market." } \\
\text { (Interviewee 2) } \\
\text { "The products delivered to the schools and } \\
\text { hospitals of the municipality contribute } \\
\text { to reducing the costs of the city hall." } \\
\text { (Interviewee 13) }\end{array}$ & $\begin{array}{l}\text { It values the work and local produce } \\
\text { and opens up the market. }\end{array}$ \\
\hline 3.3 & $\begin{array}{l}\text { Shared collective breakfast and lunch: } \\
\text { the idea came from one member as most } \\
\text { people did not have breakfast and brought } \\
\text { lunch from home because they lived in } \\
\text { distant locations. Thus, they decided to } \\
\text { share the ingredients and prepare lunch } \\
\text { with a rotational cook in COOPAVAM's } \\
\text { kitchen. }\end{array}$ & $\begin{array}{l}\text { Experienced during the period in } \\
\text { which the researcher was in the field } \\
\text { (February, 2015). }\end{array}$ & It strengthens relationships. \\
\hline 3.4 & $\begin{array}{l}\text { There is the intention to create a party } \\
\text { called the "Brazil Nut Party". }\end{array}$ & $\begin{array}{l}\text { "We contribute to the community, e.g. } \\
\text { children's day, church celebrations. We } \\
\text { will have a nuts party, like the grape } \\
\text { has." (Interviewee 1) }\end{array}$ & $\begin{array}{l}\text { The act of planning and throwing } \\
\text { this party already improves the } \\
\text { relationships. If it actually occurs, } \\
\text { there will be an improvement in the } \\
\text { community's self-esteem, and it may } \\
\text { create new forms of collaboration. }\end{array}$ \\
\hline 3.5 & $\begin{array}{l}\text { Adolescents, whether children of the } \\
\text { cooperative members or not, are allowed to } \\
\text { access the internet in the cooperative's yard, } \\
\text { allowing access to information, news, and } \\
\text { leisure activities. }\end{array}$ & $\begin{array}{l}\text { Experienced by the researcher in } 2015 \\
\text { (secondary data). }\end{array}$ & $\begin{array}{l}\text { It increases the possibility of } \\
\text { adolescents getting to know the } \\
\text { cooperative, creating sympathy for the } \\
\text { work developed and expanding their } \\
\text { knowledge through the use of the } \\
\text { network. }\end{array}$ \\
\hline 3.6 & Cultural activities in seminars. & $\begin{array}{l}\text { 2nd Meeting of rural and indigenous } \\
\text { women from northwestern Mato } \\
\text { Grosso and 2nd Seminar on Solidary } \\
\text { Economy with SAF and PFNN - } \\
\text { November 2014; } \\
\text { Participation in the 1st Indigenous } \\
\text { World Games; } \\
\text { Participation in the Olympics - 2016; } \\
\text { Participation in the X Brazilian } \\
\text { Congress on Agroforestry Systems; } \\
\text { Expoalimentaria - Peru - } 2018 \\
\text { (secondary data) }\end{array}$ & $\begin{array}{l}\text { It improves the community's self- } \\
\text { esteem and teaches habits and } \\
\text { traditions to young people. }\end{array}$ \\
\hline 3.7 & $\begin{array}{l}\text { Support from the enterprises in local } \\
\text { parties such as children's day, fathers' day, } \\
\text { mothers' day, and religious parties. }\end{array}$ & $\begin{array}{l}\text { "We have church celebrations, the nuts } \\
\text { party..." (Interviewee 14). }\end{array}$ & $\begin{array}{l}\text { It improves the relationship between } \\
\text { the community and the enterprises. It } \\
\text { also values the local culture. }\end{array}$ \\
\hline
\end{tabular}


From analyzing the type of impact promoted by cultural institutional work, we find that this kind of work is important for the creation of the institution because it increases the connectivity of the actors. According to Balestrin and Verschoore (2016), the possibility of a network accomplishing its common goals is closely linked to the capacity of its members to establish connections among themselves, as this fosters the creation of strong ties in the community.

All of these practices were purposefully used, motivated by the series of objectives listed in Table 3, and appear to be successful in consolidating collaboration in the AVA community. Considering the findings from the types of institutional work in the community, we affirm that the three types of institutional work were able to create the conditions for establishing cooperative networks: common objectives, governance, and connectivity.

\section{I.3 Main results obtained from the institutionalization of cooperation}

The field research with AVA's residents highlights that the work developed in the community and among the partners contributed to positively altering the reality of the region. For instance, the statements of I1, I3, I5, I7, I8, and I9 (see Table 7) made it possible to list some changes in AVA, considering their perceptions on economic, social, and environmental aspects.

Table 7

Main results obtained from the institutionalization of cooperation.

\begin{tabular}{ll}
\hline \multicolumn{2}{c}{ Environmental Results } \\
\hline Excerpt & Results \\
\hline "... which was initially only a concern about deforestation and environmental & Awareness of the environment; \\
issues, generated a series of positive results and a network of stakeholders focused on & Organic certification of production; \\
Brazil nut cultivation and forest preservation. "(Interviewee 1) & Activity that does not damage nature; \\
& Incentive to Brazil nut cultivation and forest \\
"Today there is a great collective awareness of everyone in the network about the & preservation; \\
importance of the forest" (Interviewee 2) & Environmental preservation; \\
& Awareness of the importance of the forest; \\
\hline
\end{tabular}

"Then this project Cultivation [...] forty-eight gardens were set up through projects to help with this issue of woman at home. So they take care of the Diversification of agricultural production; garden to sell the produce of the garden, it is already an income there for that family. And also the canning factory was built to acquire the produce of vegetable gardens and to commercialize it, not only in fresh but also in conserved form. "(Interviewee 3)

\begin{tabular}{|c|c|}
\hline $\begin{array}{l}\text { "...the monitoring of local actors has increased greatly with awareness about the } \\
\text { care that needs to be taken with the environment" (Interviewee 8) }\end{array}$ & $\begin{array}{l}\text { Minimization of the wood and ore extraction } \\
\text { activities in indigenous areas; }\end{array}$ \\
\hline $\begin{array}{l}\text { Sentinelas da Floresta project report - 1st and 2nd editions. (secondary } \\
\text { data) }\end{array}$ & $\begin{array}{l}\text { Forest conservation and settlement areas; } \\
\text { Training courses in different areas; } \\
\text { Generation of little waste; }\end{array}$ \\
\hline \multicolumn{2}{|c|}{ Economic Results } \\
\hline $\begin{array}{l}\text { "Thanks to the project, we made some special products to market. You pay the right } \\
\text { price for their products, let's say, then they start to get excited! The business pays } \\
\text { money, let's work ... You know what I mean? "(Interviewee 8) }\end{array}$ & $\begin{array}{l}\text { Indigenous people are learning to deal with } \\
\text { money; }\end{array}$ \\
\hline $\begin{array}{l}\text { "... because there are people whose family income is only from here in the } \\
\text { cooperative, so imagine how important it is..." (Interviewee 1) } \\
\text { "I'm going to work here because it's so much better than staying in town. } \\
\text { This improved the lives of many people who started to consume things they } \\
\text { could not buy. For example, now women can buy furniture and decorate } \\
\text { their houses" (Interviewee 1) }\end{array}$ & $\begin{array}{l}\text { Income in the settlement; } \\
\text { Access to consumption; }\end{array}$ \\
\hline
\end{tabular}




\begin{tabular}{|c|c|}
\hline \multicolumn{2}{|c|}{ Environmental Results } \\
\hline Excerpt & Results \\
\hline \multicolumn{2}{|l|}{ Social Results } \\
\hline $\begin{array}{l}\text { "...in this way, with the creation of the network, the Indians remained in their } \\
\text { habitat, continued hunting, did not lose their culture, and this allowed them to } \\
\text { remain there." (Interviewee 8) }\end{array}$ & $\begin{array}{l}\text { Cultivation of indigenous cultural practices (hunting, } \\
\text { family fishing); } \\
\text { Practice and dissemination of the mother tongue } \\
\text { and customs for the children of indigenous } \\
\text { peoples; }\end{array}$ \\
\hline $\begin{array}{l}\text { "Well ADERJUR, as it is an institution that has a very long history [...] in the } \\
\text { Vale do Amanhecer, basically, it supported the selection of the farmers that occupy } \\
\text { the lots [...] settlement and planning of lot demarcation." (Interviewee 2) }\end{array}$ & Legality of settlement; \\
\hline $\begin{array}{l}\text { "I became involved with the organization, I had no knowledge of how } \\
\text { a cooperative operated. An association, that was where I started to get } \\
\text { involved, to see in the most collective form of the enterprise, I had to } \\
\text { have other participations as well, I had to change the way of thinking. " } \\
\text { (Interviewee 5) }\end{array}$ & Access to information; \\
\hline $\begin{array}{l}\text { "...our focus is the indigenous people, and sustainability, you know, they take } \\
\text { sustenance from the forest without degrading the environment." (Interviewee 8) } \\
\text { "Then thanks to the project we made a set of special products for supermarkets. It } \\
\text { is possible to pay the fair price." (Interviewee 3) } \\
\text { "The Brazil nut tree is already something of their culture, but, you see, it is from } \\
\text { the culture for their own sustenance, they did not take it for profit or income, } \\
\text { right?[...] before they used it only to eat..." (Interviewee 12) }\end{array}$ & $\begin{array}{l}\text { Income generation for AVA's community; } \\
\text { Income generation for the indigenous people; } \\
\text { Construction of infrastructure for the extraction of nuts } \\
\text { for indigenous peoples; }\end{array}$ \\
\hline Observation, secondary data. & People can return to their studies after a long time; \\
\hline $\begin{array}{l}\text { Sentinelas da Floresta project report }-1^{\text {st }} \text { and } 2^{\text {nd }} \text { editions } \\
\text { (secondary data). }\end{array}$ & $\begin{array}{l}\text { Forest conservation and settlement areas; } \\
\text { Training courses in different areas; }\end{array}$ \\
\hline $\begin{array}{l}\text { "So, at the beginning of the cooperative's history women did not have } \\
\text { space, only men worked, so we started AMCA. Now women are the } \\
\text { majority in AMCA and COOPAVAM." (Interviewee 4) }\end{array}$ & Inclusion of women in production processes. \\
\hline
\end{tabular}

The main economic results are: 1) Income generation for AVA's community; 2) Income generation for the indigenous people; 3) Diversification of the agricultural production. The main social results are: 4) Legality of the settlement; 5) Access to consumption; 6) People being able to return to their studies after a long time ( 2 to higher education, 2 to elementary and high school); 7) Access to information; 8) Training courses in different areas; 9) The indigenous people learn how to handle money; 10) Practice and dissemination of the mother tongue and customs to the indigenous people's children; 11) Construction of residences for the indigenous people; 12) Cultivation of indigenous cultural practices (hunting, family fishing); 13) Inclusion of women in production processes. The main environmental results are: 14) Awareness of the environment; 15) Generation of little waste;
16) Organic certification of the production; 17) Activity which does not damage nature; 18) Conservation of the forest and settlement areas; 19) Incentive to grow Brazil nuts and preserve the forest; 20) Minimization of wood and ore extraction activities in indigenous areas; 21) Environmental preservation; 22) Awareness of the importance of the forest.

The proposed framework considered that the work practices developed by a group of social actors promote the institutionalization of cooperative behavior which, in turn, promotes results in social, economic, and environmental aspects in a vulnerable community located in the Amazon.

Our data analysis points out that the institutionalization of cooperation occurs through the development of joint projects among local actors. It is from the submission of the joint 
projects that the actors perceive and create new common goals. The existence of common objectives is the driving force in the formation of networks (Balestrin \& Verschoore, 2016).

Our analysis showed that the technical institutional work is the first that develops in the community, functioning as a motivator for the other types of work and their practices. The political work practices verified in the settlement contribute to the development of the rules and the way the network works. We showed that the decision-making process is participatory; there is little formalization of rules and little centralization of decisions, and the practices identified provide a form of participatory governance (Provan $\&$ Kenis, 2007) for the network formed in the AVA settlement. The cultural institutional work strengthens the bonds between the actors of a network, as it creates opportunities for interaction, the creation of friendships, and the creation of a collective identity. The existence of common goals is the driving force in the formation of networks, but collective strategies will hardly bring substantial gains without robust connectivity between members (Todeva, 2006).

\section{Final Remarks}

According to Mair and Marti (2009), little research has been devoted to studies that consider the role of the lack of resources, lack of power, and peripheral actors considered as marginal actors. In these situations, it would be impossible to expect one actor alone to achieve results that would modify the local reality, and so cooperation seems to be an important option. In this study, we present how the creation of an institution can be fundamental for reducing social vulnerability. The institution created in this study was a business network among actors.

Cooperation in this scenario occurs through temporary collaborative projects that have a beginning, middle, and end. As the literature observes, institutional work is dynamic and processual, which demonstrates that it is possible to create new institutions from organizational models, as suggested by Clemens (1993). In this sense, the formation of cooperation networks is established in this study as an organizational model (Thompson, 1967) that guides the process of creating an institution. Projects have been developed systematically since the foundation of AVA, involving different actors of the institutional environment where the settlement is located: government, families, indigenous communities, universities, and the civil community. The projects developed in the AVA settlement have used different forms of cooperation.

However, as indicated in Figure 2, a new arrangement was formed in which COOPAVAM plays an important link in the configuration of different dyads and triads. It was confirmed that all work practices occur recursively with the outcomes of the work developed there (Lawrence \& Suddaby, 2006), which means that as the practices meet their demands, the results promote the maintenance of work practices that foster cooperation and the creation of other practices. Interorganizational relations in the social context of the community are formalized to foster local development from established relationships with set timeframes, following an agenda of activities or projects submitted to development agencies.

This study presents the following theoretical and empirical contributions: a) it adds to the field of institutional work in socially vulnerable contexts; b) it presents a set of practices that can be replicated in similar social realities; c) we discovered a hierarchical relationship between the types of relational work to create the cooperative institution; d) we highlighted that some types of institutional work can develop different conditions for the establishment of business networks; and e) the work practices and limitations found in this social context may serve as guides to establish public policies that effectively meet the demands of these social groups.

It was possible to identify work practices that establish cooperation in relation to the demands and daily actions of the communities, that is, the creation of the institution. Cooperation 
as an institution is dynamic and processual, as presented by the authors who have studied this theoretical lens. The great challenge faced by this community is maintaining the institution. We emphasize that, to maintain a newly created institution or network, institutional work ensuring adherence to new modes of functioning and infusing the normative foundations of the new profile into the targets' daily routines and work practices must be continuously performed. Future studies could focus on identifying institutional work practices to maintain the network. Furthermore, cases of networks that have dissolved could be studied to understand which practices are used to destroy an institution.

\section{References}

Archer, M. (1995). Realist social theory: The Morphogenetic approach. Cambridge: Cambridge University Press.

Balestrin, A., \& Verschoore, J. (2016). Redes de cooperação empresarial: Estratégias de gestão na nova economia (2nd ed.). Porto Alegre: Bookmamn.

Clemens, E. S. (1993). Organizational repertoires and institutional Change: Women's groups and the transformation of US politics, 1890-1920. American Journal of Sociology, 98(4), 755-798.

DiMaggio, P. (1988). 'Interest and agency in institutional theory'. In L. Zucker (ed.). Institutional patterns and culture .Cambridge (pp. 3- 22), MA: Ballinger Publishing Company.

Dobbin, F. (2001). The business of social movements. In J. Jasper, J. Goodwin, F. Polletta. Passionate politics: Emotions and social movements (pp. 74-82). Chicago: University of Chicago Press.

Dover, G., \& Lawrence, T. B. (2010). A gap year for institutional theory: Integrating the study of trabalho institucional and participatory action research. Journal of Management Inquiry, 12(1), $1-12$.
Garud, R., Jain, S., \& Kumaraswamy, A. (2002). Institutional Entrepreneurship in the Sponsorship of Common Technological Standards: The Case of Sun Microsystems and Java. The Academy of Management Journal, 45(1), 196-214

Greenwood, R., Oliver, C., Sahlin, K., \& Suddaby, R. (2008). Introduction. In R. Greenwood, C. Oliver, K. Sahlin, R. Suddaby (eds.). The SAGE Handbook of Organizational Institutinalism (pp. 1-46). Sage Publications.

Geddes, M. (2014). Relacionamentos interorganizacionais no desenvolvimento de parcerias locais e regionais. In S. Cropper, M. Ebers, C. Huxham, \& P. S. Ring. Handbook de relaçôes interorganizacionais da Oxford (pp. 183207). UK: Bookman.

Gulati, R., \& Gargiulo, M. (1999). Where do interorganizational networks come from? American Journal of Sociology, 104(5), 1439-1493.

Gyapong, J. O., Selby, R. A., \& Anakwah, K. A. (2011). Challenges in linking health research to policy: A commentary on developing a multistakeholder response to orphans and vulnerable children in Ghana. Health Research Policy and Systems, 9(14), 1-6.

Hwang, H., \& Colyvas J. (2011). Problematizing actors and institutions in Trabalho Institucional. Journal of Management Inquiry, 20(1), 62-66.

INCRA/SR-13/T, Instituto Nacional de Colonização e Reforma Agrária - INCRA. (1996). Assentamentos. Retrieved from http:// www.incra.gov.br/assentamento

Lawrence, T. B., Suddaby, R., \& Leca, B. Introduction (2009). Theorizing and studying institutional work. In Lawrence, T.B; Suddaby, R.; Leca, B. Institutional work: Actors and agency in institutional studies of organizations (pp. 11-59). Cambridge: University Press.

Lawrence, T. B., Leca, B., \& Zilber. (2013). Institutional Work: Current research, directions 
and overlooked issues. Organization Studies, 34(8), 1023-1033.

Lawrence, T. B., \& Suddaby, R. (2006). Institutions and institutional work In: S. R. Clegg, C. Hardy, T. Lawrence, \& T. R. Nord. Handbook of organization studies (2nd ed., pp. 215-254). Sage Publications.

Lawrence, T., Suddaby, R., \& Leca, B. (2011). Institutional work: Refocusing institutional studies of organization. Journal of Management Inquiry, 20(1), 52-58.

Lincoln, Y. S., \& Guba, E. G. (1985). Naturalistic inquiry. Newbury Park, CA: Sage Publications.

Mair, J., \& Marti, I. (2009). Entrepreneurship in and around institutional voids: A case study from Bangladesh. Journal of Business Venturing, 24(5), 419-435.

Nolte, I. M., Martin, E. C., \& Boenigk, S. (2012). Cross-sectoral coordination of disaster relief. Public Management Review, 14(6), 707-730.

Nunes, P. (2013) Projeto sentinelas da floresta. Aprovado pelo Banco Fundo da Amazônia. Cooperativa dos Agricultores do Vale do Amanhecer. Juruena: COOPAVAM.

Nunes, P. C., \& Rugnitz, M. T. (2011). Semeando esperança, colhendo bens e serviços ambientais: Resultados do projeto Poço de Carbono. Associação de Desenvolvimento Rural de Juruena (ADERJUR). Juruena: ADERJUR.

Phillips, N., Lawrence, T. B. \& Hardy, C. (2004). Discourse and institutions. Academy of Management Review, 29(4), 635-652.

Provan, K. G., Fish, A., \& Sydow, J. (2007). Interorganizational networks at the network level: A review of the empirical literature on whole networks. Journal of Management, 33(3), 479-516.

Provan, K., \& Kenis, P. (2007). Modes of network governance: Structure, management, and effectiveness. Journal of Public Administration Research and Theory, 18(2), 229-252.

Schildt, H. A., Mantere, S., \& Vaara, E. (2011). Reasonability and the Linguistic Division of Labor in Trabalho Institucional. Journal of Management Inquiry, 20(1), 82-86.

Selznick, P. (1972). A liderança na administração: Uma interpretação sociológica. Rio de Janeiro: Fundação Getúlio Vargas.

Styhre, A. (2014). Gender equality as trabalho institucional: The case of the Church of Sweden. Gender, Work \& Organization, 21(2), 105-121.

Thompson, J. W. (1967). Organizations in Action. (Reprinted from New Brunswick, ed. 2003, NJ: Transaction Publishers). New York: McGraw Hill.

Todeva, E. (2006). Business networks: Strategy and structure. London: Routledge.

United Nations - Economic Commission for Latin America and Caribbean (2006). Statistical yearbook for Latin America and the Caribbean 2005. Santiago de Chile: ECLAC.

Whittington, R. (2006). Completing the practice turn in strategy research. Organization Studies, 27(5), 613-634.

Willmott, H. (2011). Institutional work for what? Problems and prospects of institutional theory. Journal of Management Inquiry, 20(1), 67-72.

Zietsma, C., \& Lawrence, T. B. (2010). Institutional work in the Transformation of an Organizational Field: The interplay of boundary work and practice work. Administrative Science Quarterly, 55(2), 189-221.

Zilber, T. B. (2007). Stories and the discursive dynamics of institutional entrepreneurship: The case of Israeli hightech after the bubble. Organization Studies, 28(7), 1035-1054). 
About the Authors:

1. Ana Maria de Lima, PhD, Universidade do Estado de Mato Grosso, Juara - Brazil.

E-mail: ana.lima@unemat.br

ORCID

(iD)0000-0002-8436-9352

2. Kadigia Faccin, PhD, Unisinos, Porto Alegre - Brazil. E-mail: kadigiaf@unisinos.br

ORCID

(iD 0000-0003-2804-2328

3. Alsones Balestrin, PhD, Unisinos, Porto Alegre - Brazil. E-mail: abalestrin@unisinos.br

ORCID

(D)0000-0001-6397-1582

4. Diego Marconatto, PhD, Unisinos, Porto Alegre - Brazil. E-mail: dmarconatto@unisinos.br

ORCID

(D)0000-0002-9458-9199

Has any preliminary version of this article been presented / published in annals of scientific congresses or is it derived from a thesis or dissertation?

No.

\section{Contribution of each author}

Each author should take responsibility for at least one component of the paper. If the article is approved for publication, the authors should indicate in the diagram below, what was the contribution of each.

\begin{tabular}{|c|c|c|c|c|}
\hline Contribution & $\begin{array}{c}\text { Ana Maria de } \\
\text { Lima }\end{array}$ & $\begin{array}{c}\text { Kadigia } \\
\text { Faccin }\end{array}$ & $\begin{array}{c}\text { Alsones } \\
\text { Balestrin }\end{array}$ & $\begin{array}{c}\text { Diego } \\
\text { Marconatto }\end{array}$ \\
\hline 1. Definition of research problem & $\sqrt{ }$ & $\sqrt{ }$ & $\sqrt{ }$ & \\
\hline 2. Development of hypotheses or research questions (empirical studies) & $\sqrt{ }$ & $\sqrt{ }$ & $\sqrt{ }$ & \\
\hline 3. Development of theoretical propositions (theoretical work) & $\sqrt{ }$ & $\sqrt{ }$ & & \\
\hline 4. Theoretical foundation/Literature review & $\sqrt{ }$ & $\sqrt{ }$ & & \\
\hline 5. Definition of methodological procedures & $\sqrt{ }$ & $\sqrt{ }$ & & \\
\hline 6. Data collection & $\sqrt{ }$ & & & \\
\hline \multicolumn{5}{|l|}{ 7. Statistical analysis } \\
\hline 8. Analysis and interpretation of data & $\sqrt{ }$ & $\sqrt{ }$ & & \\
\hline 9. Critical revision of the manuscript & & $\sqrt{ }$ & $\sqrt{ }$ & \\
\hline 10. Manuscript writing & $\sqrt{ }$ & $\sqrt{ }$ & & \\
\hline 11. Other (please specify which) & & & & \\
\hline
\end{tabular}

This information will be available in publications as an end notal in accordance with the criteria, policies and procedures for admission and permanence of scientific journals in SciELO Brazil Collection.

\section{Erratum}

Where was written:

“Review of Business Management, São Paulo, v.21, n.4, p.683-705, oct/dec. 2019”

Now read:

“Rev. Bras. Gest. Neg. São Paulo v.21, Special Issue. 2019 p. 683-705” 